\title{
IMPACT OF CONSOLIDATION PROCEDURES ON THE IMPLEMENTATION OF THE INFORMATION ACCOUNTING FUNCTION
}

\author{
Artur Jastrzebowski ${ }^{1}$ \\ Zofia Wierzbinska ${ }^{2}$ \\ Marek Wierzbinski ${ }^{3}$
}

DOI: https://doi.org/10.31410/ITEMA.2019.125

\begin{abstract}
Financial reporting is often referred to as the result of all activities undertaken within the accounting system. As an element of financial accounting, it is associated with the implementation of various functions attributed to accounting. However, the area of financial reporting itself is divided into two elements - single reporting and consolidated reporting. Consolidated reporting is a characteristic process with its own procedures and assumptions. Therefore, the question should be asked whether the differences do not affect the implementation of the basic accounting function - information function.

The purpose of the article is to present the impact of implementing the characteristic procedures of the financial statements consolidation process on the implementation of the accounting information function.

The study was divided into three parts, preceded by an introduction and completed with conclusions. The first part describes the essence of the accounting function with particular emphasis on the information function. The second part presents a model process of consolidating financial statements according to IFRS regulations. The last section of the study presents an analysis of the characteristic points of the consolidation process and assesses their impact on the implementation of the accounting information function.
\end{abstract}

The work was based on the method of analyzing literature sources, the comparative method and the method of synthesis.

Keywords: Information Accounting Function, Consolidation, Financial Statement.

\section{INTRODUCTION}

Zinancial reporting is often referred to as the result of all activities undertaken within the accounting system. As an element of financial accounting, it is associated with the implementation of various functions attributed to accounting. However, the area of financial reporting itself is divided into two elements - single reporting and consolidated reporting. Consolidated reporting is a characteristic process with its own procedures and assumptions. Therefore, the question should be asked whether the differences do not affect the implementation of the basic accounting function - information function.

Poznań University of Economics and Business, Department of Accounting and Financial Audit, al. Niepodleglosci 10, 61-875, Poznan, Poland

2 Poznań University of Economics and Business, Department of Management Accounting, al. Niepodleglosci 10, 61-875, Poznan, Poland

3 Poznań University of Economics and Business, Department of Management Accounting, al. Niepodleglosci 10, 61-875, Poznan, Poland 


\section{THE ESSENCE OF THE ACCOUNTING INFORMATION FUNCTION}

According to many theorists (Butterworth 1972; Feltham, 1968; Gos 2008), the essence of accounting is closely related to the generation and processing of information. Moreover, the involvement of accounting in the process of supporting managerial decision making through the provision of appropriately tailored information is so large that some scientists define it as an information system (Kunz \& Tymińska, 2014, p. 44).

The importance that is assigned to the process of handling information by the accounting system causes that the information function is often recognized as the primary accounting foundation (Brzezin 1998).

The subject of interest in this area is information understood as a product of the accounting system, presented to recipients in an aggregated form with the use of financial statements of entities (International Financial Reporting Standards 2014, p. 36). All processes in the company's accounting focus on processing data as a resource obtained by the accounting system into information that is a product of its operations.

The features of information depend on the accounting subsystem under which they were prepared. According to the International Financial Reporting Standards (2014, p. 42), information in the financial statements should be characterized by two fundamental features:

- Usefulness,

- faithful presentation.

The usefulness of information should be considered as the impact of information on changing the user's decision (International Financial Reporting Standards 2014, p. 42-43).

On the other hand, a faithful presentation means that the information should present transactions and other events that took place in a business unit. Information having the feature of faithful presentation is complete, impartial and it does not contain errors (Rówińska 2013, p. 377).

The unambiguous description in the literature that the described accounting function provides information for the needs of the entity's management and for external recipients is an expression of the fact that in the accounting theory it can be distinguished (Poetschke 2011, p. 16):

- external information function,

- internal information function.

It is generally believed that financial accounting, i.e. one of the accounting subsystems, is responsible for the provision of information to external users. Its goal is to show the company's assets and capital, as well as to register factors that shape the entity's financial result. Information created as a part of the financial accounting is retrospective and constitutes the main source of shaping the image of the entity. Provision of information for external stakeholders is realized (mainly) via financial statements (Kurek \& Zielińska 2000, p. 145-146).

It should be noted that the growing economic risk increases the scope of information about the entity desired by external users. This process forces the continuous evolution of financial statements and the entire accounting system in such a way that accounting can provide information for the largest possible group of stakeholders. 
The internal information function is realized by both the financial accounting and management accounting subsystems. Information generated by financial accounting is not sufficient for the needs of making optimal economic decisions by the entity's management.

According to Kurek and Zielińska (2000, p. 147), one of the reasons for this situation is a high degree of formalization in obtaining information within the framework of the financial accounting. According to the above-mentioned authors, the emerging gap is filled with management accounting, which is focused on supporting the decision-making process. The information generated in the management accounting subsystem is informal and it is largely shaped by individual needs of the entity's management. They are based on data expressed both in monetary measure and in natural units.

An important aspect of information generated as a part of management accounting is its orientation, not only on the past, but also the future of the entity. The generated information enables the development of plans that show different variants of the formation of assets, sources of financing and the entity's financial result.

In conclusion, it should be stated that the essence of the information function is to provide information for decision-making purposes in a complex manner - both to external users (mainly information from the financial accounting subsystem) and internal users (in particular, information from the management accounting subsystem).

The subject of interest of this article is the area of the external accounting function that presents information with the use of financial statements. There is a question - how do the procedures implemented in the process of preparing the consolidated financial statements affect the performance of the information function?

\section{SHAPE OF THE CONSOLIDATION PROCESS IN FINANCIAL STATEMENTS}

The process of consolidating financial statements is (in essence) an implication of the accounting principle of the superiority of economic content over form. The basis for the need to implement the consolidation process is the occurrence of a special relation between two entities. Among the entities operating on the market, there may be three groups of impacts, presented in the figure below.

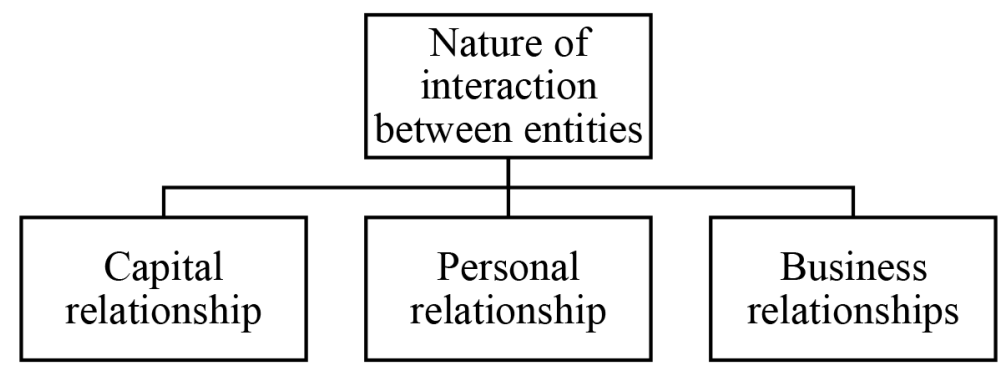

Figure 1. Types of relations between enterprises

Source: Own study

The first of the presented forms of impact has the most formal character. The connection between entities results from the capital involvement of one entity in another entity. It is also the most transparent and easily traceable type of connection. Impact bases can be highlighted on the basis of specific assets and liabilities of units. 
The second type of relationship has a less formal nature in relation to the capital relationship. In this case, the entities do not engage their capital, but their relationship results from personal relationships. A condition for the occurrence of a personal relationship is connected with making decisions in operational and financial policy by allied people.

The last of the identified types of business combinations and the least formal interaction is a purely business relationship. It occurs when entities are not related by capital or personnel. However, due to specific market conditions, one entity can actively influence the activities of another business entity.

Despite the fact that from the point of view of conducting business activity, each of these forms of impact can significantly affect the functioning of the entity, according to many regulations (including regulations contained in the International Financial Reporting Standards (IFRS no.10)), the consolidation process covers only interactions with a capital nature.

However, it would be incorrect to believe that each form of capital involvement will result in the need to prepare the consolidated financial statements. In this regard, the power of influence should be decisive. The figure below shows models of capital involvement.

„ordinary"
investment

Figure 2. The impact of companies

Source: Own study

The „ordinary investment” is the least engaging form of capital relationship. In this case, the entity acquired shares in another entity, but it is not interested in being an active owner. In most cases, such an acquisition has a purely speculative nature.

Another form of interaction is the significant impact. In this case, the entity wants to remain an active investor and it wants to have an impact on the functioning of the subordinate entity. However, the number of shares or other conditions prevent this entity from making autonomous decisions.

The entity exerts greater impact on a subordinate entity in the case of joint control - when in consultation with another co-owner (on the principles of consensus) binding operational and financial decisions regarding the subordinate entity are made.

The strongest form of influence is control, i.e. the situation when the parent entity can autonomously manage the operations of the subordinate entity. According to the definition presented in paragraph 6 of the standards (IFRS 10), the investor exercises control over an entity, in which an investment has been made, when (due to his involvement in this entity) he is exposed to variable financial results or when he has the right to variable financial results and the ability of influence the amount of these financial results by exercising power over the entity.

In conclusion, according to paragraph 7 of the regulation (IFRS 10), the investor exercises control over the investee, when the investor (simultaneously):

- exercises authority over the entity, in which the investment was made, 
- due to his involvement in this entity, in which the investment was made, he is exposed to variable financial results or has right to variable financial results,

- has the possibility of using the power to exert influence on the amount of his financial results.

While evaluating whether he exercises control over the investee, the investor takes into account all facts and circumstances. The investor reassesses whether he exercises control over this entity - if the facts and circumstances indicate that there has been a change in one or more of the three control elements listed above (IFRS 10, par. 8).

When specifying the issue of exercising power, the regulations specify (IFRS 10, par. 10-14) that the investor has power over the investee, if the current rights give him the ability to manage relevant areas in the area of shaping operational and financial policy on a current basis. The power results from the possessed rights. Sometimes the evaluation of power is obvious. For example, when it is obtained directly and exclusively from voting rights granted on the basis of capital instruments such as shares and then it can be assessed taking into account the voting rights from these shares. In other cases, the assessment is more complex and it will require consideration of more than one factor - for example, when the power results from one or more contractual arrangements. An investor (with the ability to control the relevant activities on an ongoing basis) has the power even when these rights have not been exercised yet. An evidence that the investor has exercised his right to control the relevant activities can help in determining whether the investor has power (while this type of evidence is not sufficient to determine whether the investor has power over the investee). However, the investor, who only has protective rights, has no power over the investee and (consequently) he has no control over this entity.

Ultimately, the power can be understood as active influence in the following areas (IFRS 10, par. B11-B12):

- sale and purchase of goods and services,

- management of financial assets during their lifetime (including defaults),

- selection, acquisition and disposal of assets,

- conducting research and development works regarding new products and processes,

- establishing the financing structure or obtaining financing,

- making operational and capital decisions regarding the investee, including setting budgets,

- appointing and paying for key management personnel of the unit, in which investments were made, or service providers, as well as terminating service contracts or employment contracts with them.

Compliance with the guidelines contained in the above regulations enables to identify the occurrence of impacts in the form of control. This, in turn, involves the use of the full consolidation method in the process of preparing the consolidated report.

The consolidation procedure of full method (itself) will not always be carried out in the same way and it depends on the time of its implementation. There are two characteristic moments for the preparation of the consolidated financial statements:

- moment of the purchase of shares,

- any other balance sheet day.

In accordance with paragraph B86 of the standard (IFRS 10), consolidation includes: 
- grouping of similar items in assets, liabilities, equity, revenues, costs and cash flows of the parent entity and its subsidiaries;

- compensation (excluding) of the carrying amount of the parent entity's investment in each of subsidiaries and the portion of the equity of each subsidiary that corresponds to the parent entity's share (IFRS 3 explains how to recognize the goodwill arising in this situation),

- total exclusion of assets and liabilities, equity, revenues, costs and cash flow of the capital group relating to transactions between entities of this capital group (profits and losses, related to transactions within this group that are recognized as assets such as inventories and fixed assets, are completely excluded). Losses on transactions within the group can mean impairment that requires indication in the consolidated financial statements.

As a consequence, the shape of the exemplary full consolidation procedure (at the time of acquisition) is presented in the figure below.

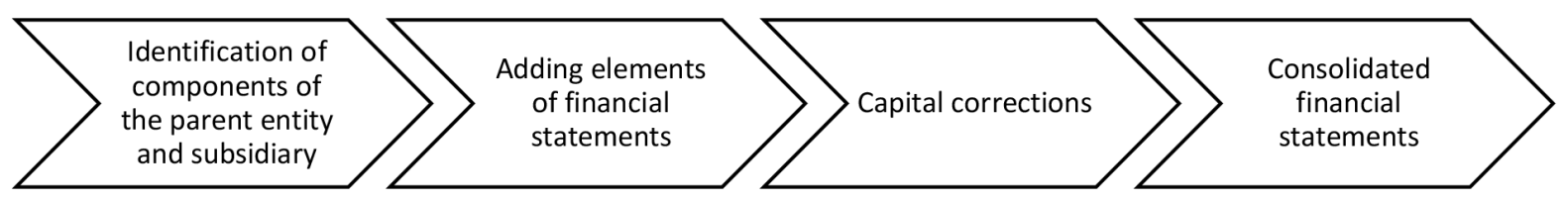

Figure 3. Consolidation procedure at the time of the purchase of shares

Source: Own study

The consolidation process (at each balance sheet date following the date of acquisition of shares guaranteeing control) constitutes both the repetition and continuation of the sequence at the time of purchase. The reference system is shown below.

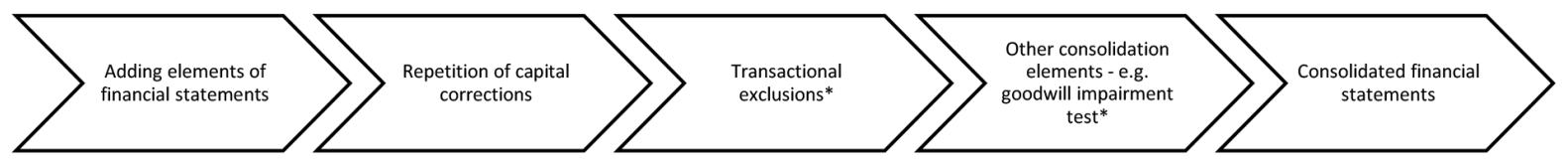

Figure 4. Consolidation procedure as at the balance sheet date

Source: Own study

It should be noted that the elements marked with the symbol ,*" are not mandatory. Their occurrence depends on actual conditions, and in particular on the transactions concluded between the entities belonging to the capital group and on the relation between the purchase price of shares and the fair value of the acquired assets (net).

The next section discusses individual stages of the consolidation process in the context of their impact on the implementation of the information accounting function.

\section{IMPACT OF CONSOLIDATION PROCEDURES ON THE IMPLEMENTATION OF THE INFORMATION FUNCTION}

As it was indicated, the information accounting function focuses on the provision of information to various user groups in order to support their decision-making processes. However, in order to understand its correlation with the consolidation process, it is necessary to consider who is the user of the consolidated financial statements. 
Various groups of users of financial statements are identified in the literature, in particular (Cole, Branson \& Breesch 2011, p. 110):

- auditors,

- shareholders,

- investors,

- employees,

- creditors,

- consultants,

- competitors,

- tax authorities.

However, not all of these users are equally interested in the information from the consolidated financial statements. For example, investors or lenders will use the consolidated report mostly to assess the immediate environment of the entity, as well as to assess the opportunities and threats related to the functioning of the entity within the capital group.

Undoubtedly, the main users of information from the consolidated financial statements are the owners. Their goal is to obtain (through this report) the answer to the question: how much is their property worth (which is formally separated into individual companies included in the capital group). As a consequence, the positive impact of consolidation procedures will be exerted when the application of the procedure makes the presented value real (from the point of view of the parent entity's owner).

Apart from the process of identifying the entities belonging to the capital group, the combination of individual reports concerning entities included in the capital group should be considered as the first stage of the consolidation procedure. Of course, taking into account the main owner's information need, summing up the data of individual entities enables to obtain the aggregated information about the value of property. However, further analysis shows that simply addition of individual items can contribute to double recognition of individual categories of assets, sources of financing, revenues and costs. Therefore, abandoning the consolidated financial statement at this stage would contribute to the reduction of its usefulness, and thus to diminishing the importance of the information function.

Therefore, after summing up the reports, there should be a stage related to the correction of the data obtained in accordance with paragraph B86 of the standard (IFRS 10). Initially, capital adjustments are conducted in order to:

- correct the double recognition of capitals and assets, by removing the acquisition value of shares held by the parent company in subsidiaries and by eliminating the equity of individual subsidiaries,

- consider the goodwill / profit on a bargain purchase,

- consider the non-controlling share.

Removal of the purchase price of shares and equity of the subsidiary enables to avoid double disclosure of subordinate entity's assets and capitals contributed by owners to the group within the framework of business financing. The correct implementation of the procedure enables to obtain the value of „clean” assets and sources of financing. This, in turn, can be the basis for the evaluation of the entire capital group's value, and thus the property belonging to its superior owners. 
However, it should be remembered that capital adjustments cannot always be limited to the removal of the purchase price for shares and equity. If there are differences between the purchase price and the fair value of the net assets and the acquisition of a majority of shares rather than an overall block of shares, it will also be necessary to include other elements that will enable to balance the consolidated financial statements.

The difference in the valuation of the subsidiary's shares and assets may result in the creation of a category of goodwill or profit on a bargain purchase. In addition to enabling the balancing of assets and liabilities in the consolidated statements, both elements will also provide information about the actual relationships between entities at the time of acquisition of shares and about the opportunities or threats facing the subsidiary. Therefore, the owner obtains not only data about the market value of subsidiaries, but also data about its expected future shape.

The value of non-controlling interests determined on the basis of the regulations of IFRS (IFRS 10), and in particular paragraphs B89 and B90, enables not only to fill the accounting gap created after the initial reduction of assets and liabilities, but also to obtain information that goes beyond the standard information resource determined in a separate statement of financial position. While in the case of separate statements, capital is presented from the point of view of all owners, the separation of non-controlling interests, i.e. the value of capital attributable to minority shareholders of the subsidiary, in the consolidated statements allows for a clear separation of the values attributable to owners of the parent entity and donors of the capital (from outside the group).

The next phase includes corrections related to the effects of transactions within the capital group. In particular, the following corrections are recognized at this stage:

- revenues and expenses,

- receivables and liabilities,

- unrealized profits retained in inventory,

- unrealized profits retained in other assets.

Pursuant to paragraph B86 of the standard (IFRS10), the aim of the above categories and their equivalent is to clean the consolidated financial statements from the effects of transactions that took place within the group in a given period. Again, the implemented procedure not only corrects information errors arising in the first step (involving the collection of financial statements), but it also provides new data covering aggregated information about transactions conducted within the group. The owner can easily control both the volume and structure of sales and purchases, as well as the margins realized in these processes.

The last of the listed characteristic elements of the consolidation process covers other corrections, including:

- goodwill impairment test,

- determination of the value of non-controlling shares.

In the event of the acquisition of assets with the book value lower than the value of the acquired shares, the resulting difference is referred to as goodwill. It is presented as an asset. As already mentioned, this process (carried out at the time of capital corrections) can be considered positively in the context of the implementation of the information accounting function. However, this category also involves the procedure for updating the value of newly created assets. 
Goodwill is reduced in accordance with the IFRS regulations when the value of the cash-generating unit (on which goodwill is based) is lower than its carrying amount. From the point of view of the information function's implementation, accounting departments are forced to verify the value of cash-generating units, and thus the owner can easily verify whether impairment of these areas of activity is realized in accordance with the adopted assumptions (whether it does not require in-depth analysis).

The last of these areas are non-controlling interests. As in the case of goodwill / profit on a bargain purchase, the identification and disclosure of items in the statement of financial position enables to maintain the correct performance of the information function. Further actions related to the revaluation (based on paragraph B94 IFRS 10) enable to obtain aggregated data that divides the generated net assets into the part attributable to owners of the parent entity and to the remaining part for third parties involved in subsidiaries.

\section{CONCLUSION}

The essence of the information function is to provide internal and external users with information about the entity in a complex manner and enabling them to make rational decisions on the basis of the obtained information. The article focuses on the external aspect of the information function - where information (mainly from the financial accounting system) serves users, who do not have direct access to the functioning of the entity.

The economic situation leads to the formation of various relationships and connections between enterprises. This causes that the financial results of various entities mix with each other. Economic and personal connections between entities do not affect their financial reporting - unlike capital connections. This makes it possible to present the result of related entities as a whole - which is justified, because thanks to the possession of a capital share in another entity, the company becomes (in a sense) an owner of its assets along with the liabilities. Moreover, the company has the right to participate in profits of this entity. Therefore, these rights are indirectly attributed to the owners of the parent company. The owners may be interested in comprehensive information about the property and financial situation, as well as the financial result of the group (as a whole).

In order to ensure the presentation of this information and the implementation of the information function (especially in the external aspect), consolidated financial statements are prepared. This article presents the procedure for preparing such reports and the impact of specific consolidation procedures on the implementation of the information function, taking into account the areas interested in this information.

\section{REFERENCES}

Bedford, N. M. \& Onsi, M. (1966). Measuring the value of information-an information theory approach. Management Services, 1, 16.

Brzezin, W. (1998). Ogólna teoria rachunkowości, Częstochowa, Publisher: Wydawnictwo Politechniki Częstochowskiej.

Butterworth, J. E. (1972). The Accounting System as an Information Function. Journal of Accounting Research, 10(1), 1-27. https://doi.org/10.2307/2490216 
Cole, V., Branson, J. \& Breesch, D. (2011). The illusion of comparable European IFRS financial statements. Beliefs of auditors, analysts and other users. Accounting and Management Information Systems, 10(2), 106-134. http://dx.doi.org/10.2139/ssrn.1521445

Feltham, G. A. (1968). The Value of Information. The Accounting Review 43(4). 684-696. https:// www.jstor.org/stable/243630

Gos, W. (2008). Wybrane uwagi na temat istoty rachunkowości, Zeszyty Teoretyczne Rachunkowości, (44), 69-78.

International Accounting Standards Board (2014). Międzynarodowe Standardy Sprawozdawczości Finansowej. Wedtug stanu na dzień 1 stycznia 2013r., Warszawa, Publisher: SKwP.

International Accounting Standards Board (2017). IFRS 10 Consolidated Financial Statements.

Kunz, B. \& Tymińska, A (2014). System informatyczny rachunkowości i jego rola w świetle ustawy o rachunkowści. Financial Science, 3(20), 44-58. https://doi.org/10.15611/ nof.2014.3.03

Kurek, H. \& Zielińska, H. (2000), Informacyjna funkcja rachunkowości. Zeszyty naukowe Akademii Ekonomicznej w Krakowie, 553, 139-149.

Poetschke, H. (2011). Istota systemu rachunkowości. Podstawy Rachunkowości, Poznań, Publisher: Wydawnictwo Uniwersytetu Ekonomicznego w Poznaniu.

Rówińska, M. (2013). Cechy jakościowe sprawozdania finansowego jednostek gospodarczych. Zeszyty Naukowe Uniwersytetu Szczecińskiego, 757, 375-382. http://www.wneiz.pl/nauka_wneiz/frfu/58-2013/FRFU-58-375.pdf 